\title{
Possible Role of P-450 Metabolite of Arachidonic Acid in Vasodilator Mechanism of Angiotensin II Type 2 Receptor in the Isolated Microperfused Rabbit Afferent Arteriole
}

\author{
Shuji Arima, Yoshimi Endo, Hiraku Yaoita, Ken Omata, Susumu Ogawa, Kazuo Tsunoda, Michiaki Abe, Kazuhisa Takeuchi, \\ Keishi Abe, and Sadayoshi Ito \\ The Second Department of Internal Medicine, Tohoku University School of Medicine, Sendai, 980-77, Japan
}

\begin{abstract}
Although angiotensin II type $2\left(\mathrm{AT}_{2}\right)$ receptor has recently been cloned, its functional role is not well understood. We tested the hypothesis that selective activation of $\mathrm{AT}_{2}$ receptor causes vasodilation in the preglomerular afferent arteriole (Af-Art), a vascular segment that accounts for most of the preglomerular resistance. We microperfused rabbit AfArts at $60 \mathrm{mmHg}$ in vitro, and examined the effect of angiotensin II (Ang II; $10^{-11}-10^{-8} \mathrm{M}$ ) on the luminal diameter in the presence or absence of the Ang II type 1 receptor antagonist CV11974 (CV; $\left.10^{-8} \mathrm{M}\right)$. Ang II was added to both the bath and lumen of preconstricted Af-Arts. Ang II further constricted Af-Arts without CV (by $74 \pm 7 \%$ over the preconstricted level at $\left.10^{-8} \mathrm{M} ; P<0.01, n=7\right)$. In contrast, in the presence of $\mathrm{CV}$, Ang II caused dose-dependent dilation; Ang II at $10^{-8} \mathrm{M}$ increased the diameter by $29 \pm 2 \%(n=7$, $P<0.01$ ). This dilation was completely abolished by pretreatment with an $\mathrm{AT}_{2}$ receptor antagonist PD123319 $\left(10^{-7} \mathrm{M}\right.$, $n=6$ ), suggesting that activation of $\mathrm{AT}_{2}$ receptor causes vasodilation in Af-Arts. The dilation was unaffected by inhibiting either nitric oxide synthase $(n=7)$ or cyclooxygenase $(n=7)$, however, it was abolished by either disrupting the endothelium $(n=10)$ or inhibiting the cytochrome P-450 pathway, particularly the synthesis of epoxyeicosatrienoic acids (EETs, $n=7)$. These results suggest that in the Af-Art activation of the $\mathrm{AT}_{2}$ receptor may cause endothelium-dependent vasodilation via a cytochrome P-450 pathway, possibly by EETs. (J. Clin. Invest. 1997. 100:2816-2823.) Key words: endothelium - arachidonic acid - cytochrome P-450 epoxygenase $\bullet$ miconazole $\bullet$ glomerular hemodynamics
\end{abstract}

\section{Introduction}

Angiotensin II (Ang II), ${ }^{1}$ the physiologically active component of the renin-angiotensin system, plays an important role in regulation of blood pressure and homeostasis of body fluid and electrolytes. Based on their different pharmacological and biochemical properties, two distinct subtypes of Ang II recep-

Address correspondence to Sadayoshi Ito, M.D., Ph.D., The Second Department of Internal Medicine, Tohoku University School of Medicine, 1-1 Seiryo-cho, Aoba-ku, Sendai, 980-77, Japan. Phone: 8122-717-7163; FAX: 81-22-717-7168.

Received for publication 23 January 1997 and accepted in revised form 14 October 1997.

J. Clin. Invest.

(C) The American Society for Clinical Investigation, Inc. 0021-9738/97/12/2816/08 \$2.00

Volume 100, Number 11, December 1997, 2816-2823

http://www.jci.org tor have been defined and designated as type $1\left(\mathrm{AT}_{1}\right)$ and type 2 $\left(\mathrm{AT}_{2}\right)$ receptors (1-3). Most of the well-characterized actions of Ang II (such as vasoconstriction, cell proliferation, and aldosterone release) are now generally considered to result from stimulation of $\mathrm{AT}_{1}$ receptors (3). On the other hand, the functional role of $\mathrm{AT}_{2}$ receptor is not well defined. Ichiki et al. (4) recently demonstrated that mice lacking the gene encoding the $\mathrm{AT}_{2}$ receptor have a higher blood pressure than the wild-type control, while Munzenmaier and Greene (5) reported that $\mathrm{AT}_{2}$ receptor blockade augments the pressor effect of Ang II in the rat. These findings suggest that $\mathrm{AT}_{2}$ receptor mediates vasodilation, thereby playing an important role in the control of blood pressure. Neither the target vasculature nor the underlying mechanism, however, is well understood. In this study we directly examined the $\mathrm{AT}_{2}$ receptor-mediated action of Ang II on renal arterioles. Thus, since it is a crucial vascular segment to the control of glomerular hemodynamics, we isolated and microperfused rabbit glomerular afferent arteriole (Af-Art). We examined whether blockade of $\mathrm{AT}_{1}$ receptor uncovers the dilator action of Ang II, and if so, whether $\mathrm{AT}_{2}$ receptor is involved in the vasodilation, and finally the mechanism involved in $\mathrm{AT}_{2}$ receptor-mediated dilation.

\section{Methods}

Isolation and microperfusion of the rabbit Af-Art We used previously described methods to isolate and microperfuse Af-Arts (6-9). In brief, young male New Zealand white rabbits $(1.5-2.0 \mathrm{~kg})$ fed standard rabbit chow and tap water ad libitum were anesthetized with intravenous sodium pentobarbital $(40 \mathrm{mg} / \mathrm{kg})$, and their kidneys were removed. From each rabbit, a single superficial Af-Art with its glomerulus (but not macula densa or other tubular segments) intact was microdissected under a stereomicroscope (SZH-10; Olympus, Tokyo, Japan). Using a micropipette, the Af-Art was transferred to a temperature-regulated chamber mounted on an inverted microscope (IMT-2; Olympus). The Af-Art was then cannulated with an array of glass pipettes and perfused at $60 \mathrm{mmHg}$ throughout the experiments with oxygenated medium 199 (GIBCO BRL, Gaithersburg, MD) containing 5\% BSA (Sigma Chemical Co., St. Louis, MO). The bath was identical to the arteriolar perfusate except that it contained $0.1 \%$ BSA, and was exchanged continuously. Microdissection and cannulation of the Af-Art were completed within $90 \mathrm{~min}$ at $8^{\circ} \mathrm{C}$, after which time the bath was gradually warmed to $37^{\circ} \mathrm{C}$. Once the temperature was stable, a 30-min equilibration period was allowed before taking any measurements. Images of Af-Arts were displayed at magnifications up to $1,980 \times$ and recorded with a video system consisting of a camera (CS520MD; Olympus), monitor (PVM1445MD; Sony, To-

1. Abbreviations used in this paper: 7-ER, 7-ethoxyresorfin; AA, arachidonic acid; Ach, acetylcholine; Af-Art, afferent arteriole; Ang II, angiotensin II; $\mathrm{AT}_{1}$ receptor, angiotensin II type 1 receptor; $\mathrm{AT}_{2}$ receptor, angiotensin II type 2 receptor; EET, epoxyeicosatrienoic acid; Indo, indomethacin; L-NAME, NG-nitro-L-arginine methyl ester; NO, nitric oxide; TEA, tetraethylammonium. 
kyo, Japan), and video recorder (HR-S101; Victor, Tokyo, Japan). Using this system, a change in luminal diameter as small as $0.5 \mu \mathrm{m}$ is detectable. The diameter at the most responsive point to Ang II was measured with a video micrometer (VM-30; Olympus).

\section{Experimental protocols}

1. Blockade of $A T_{1}$ or $A T_{2}$ receptor. We used CV11974 (2-ethoxy1([2'-[1H-tetrazol-5-ly]biphenyl-4-yl]methyl)-1H-benzimidazole-7-carboxylic acid) (CV; Takeda Pharmaceutical Co., Osaka, Japan) as a specific $\mathrm{AT}_{1}$ receptor antagonist $(3,10)$ and PD123319 ([S]-1-[[4[dimethylamino]-3-methylphenyl]methyl]-5-[diphenylacetlyl]-4,5,6,7tetrahydro-1H-imidazo[4,5-c]pyridine-6-carboxylic acid) (PD; ParkeDavis Laboratories, Ann Arbor, MI) as a specific $\mathrm{AT}_{2}$ receptor antagonist $(3,11,12)$. On the day of the experiment, a fresh solution containing either CV $11974(\mathrm{CV})$ at $10^{-6} \mathrm{M}$ or PD at $10^{-4} \mathrm{M}$ was prepared in saline with or without $0.01 \%$ DMSO (Sigma Chemical Co.), respectively. After the equilibration period, $\mathrm{CV}$ vehicle, $\mathrm{CV}$ (at $10^{-9} \mathrm{M}$ or $10^{-8} \mathrm{M}$ ) or PD (at $10^{-7} \mathrm{M}$ ) was added to both the bath and lumen. These doses of CV or PD have been demonstrated to be specific for $\mathrm{AT}_{1}(10)$ or $\mathrm{AT}_{2}$ receptor $(11,12)$, respectively. 30 min later, increasing doses of Ang II $\left(10^{-11}-10^{-8} \mathrm{M}\right.$; Sigma Chemical Co.) were added to both the bath and lumen. Luminal diameter was measured immediately before adding Ang II and observed for at least $10 \mathrm{~min}$ at each dose.

2. Blockade of $A T_{1}$ receptor alone or both $A T_{1}$ and $A T_{2}$ receptors in preconstricted Af-Arts. We examined the possibility that blocking $\mathrm{AT}_{1}$ receptors uncovers the vasodilatory action of Ang II, and if so, possible involvement of $\mathrm{AT}_{2}$ receptors. For this purpose, Af-Arts were preconstricted with norepinephrine (NE), since the isolated AfArt has little intrinsic tone, making it difficult to observe its dilator responses. After the equilibration period, $\mathrm{CV}$ vehicle, $\mathrm{CV}$ at $10^{-8} \mathrm{M}$ (which completely abolished Ang II-induced constriction in protocol $1)$, or CV $\left(10^{-8} \mathrm{M}\right)$ plus PD $\left(10^{-7} \mathrm{M}\right)$ was added to both the bath and lumen. 30 min later, Af-Arts were preconstricted by $\sim 40 \%$ with $\mathrm{NE}$ ( $0.5 \mu \mathrm{M}$, Sigma Chemical Co.), and then effects of Ang II were examined as in protocol 1. In a previous study (9) we have demonstrated that $\mathrm{NE}$ at this concentration causes stable and sustained constriction of rabbit Af-Arts for $3 \mathrm{~h}$ (which is much longer than needed to complete any experimental protocol performed in this study).

3. Disruption of the endothelium. We found that in CV-treated and preconstricted Af-Arts, Ang II causes dose-dependent dilation that is abolished by simultaneous pretreatment with $\mathrm{PD}$, suggesting that activation of the $\mathrm{AT}_{2}$ receptor causes vasodilation in Af-Arts (see Results). We then examined the possible contribution of the endothelium to this dilation. After the equilibration period, Af-Arts were perfused for $10 \mathrm{~min}$ with perfusate containing both antibodies against human factor VIII-related antigen $(14.29 \mathrm{mg} / \mathrm{ml}$; Atlantic Antibodies, Stillwater, MN) and 2\% guinea pig complements (Sigma Chemical Co.). This perfusion was followed by a 20 -min washout period during which Af-Arts were perfused with perfusate containing neither antibodies nor complements. We have previously demonstrated that this treatment selectively disrupts endothelial cells without altering the function of vascular smooth muscle cells (13-15). After disrupting the endothelium, Af-Arts were treated with CV $\left(10^{-8} \mathrm{M}\right)$ and constricted with $\mathrm{NE}$ at $0.5 \mu \mathrm{M}$. The effect of Ang II was then examined as in protocol 2. At the end of each experiment, we confirmed that Af-Arts did not dilate in response to acetylcholine (Ach, $10 \mu \mathrm{M}$; Sigma Chemical Co.), an endothelium-dependent vasodilator.

4. Inhibiting synthesis of endothelium-derived vasodilators. Since disruption of the endothelium abolished the dilator response in protocol 3 (see Results), we examined the possible contribution of endotheliumderived vasodilators by blocking synthesis of nitric oxide (NO), prostaglandins (PGs), or epoxyeicosatrienoic acids (EETs), cytochrome P-450 epoxygenase-dependent vasodilators. NO synthesis was inhibited with NG-nitro-L-arginine methyl ester (L-NAME, Sigma Chemical Co.) at $10^{-4} \mathrm{M}$, which blocks Ach-induced vasodilation in rabbit Af-Arts (8). Cyclooxygenase activity was inhibited as described pre- viously with indomethacin (Indo; Sigma Chemical Co.) at $5 \times 10^{-5} \mathrm{M}$, which blocks the effect of arachidonic acid $\left(\mathrm{AA} ; 10^{-4} \mathrm{M}\right)$ on renin release in rabbit Af-Arts (16). EETs synthesis was inhibited with an epoxygenase inhibitor miconazole (Sigma Chemical Co.) at $10^{-6} \mathrm{M}$ that selectively inhibits formation of EETs by $\sim 90 \%$ in rat preglomerular microvessels incubated with AA (17). Care was taken to keep the miconazole solutions from light. After the equilibration period, Af-Arts were treated with both $\mathrm{CV}\left(10^{-8} \mathrm{M}\right)$ and one of the three inhibitors for $30 \mathrm{~min}$. Af-Arts were then preconstricted with NE, and effects of Ang II were examined as in protocol 2.

5. Inhibiting cytochrome P-450 activity. We found that pretreatment with miconazole completely abolishes dilation of Af-Arts in protocol 4 (see Results). To exclude the possibility that this was due to a nonspecific effect of miconazole on vascular reactivity, we examined the effect of 7-ethoxyresorfin (7-ER), which inhibits cytochrome P-450-dependent arachidonate metabolism and thereby decreases EETs synthesis. After the equilibration period, Af-Arts were treated with both $\mathrm{CV}\left(10^{-8} \mathrm{M}\right)$ and 7-ER (BIOMOL Research Laboratories, Inc., Plymouth Meeting, PA) at $10^{-6} \mathrm{M}$ for $30 \mathrm{~min}$. Af-Arts were then preconstricted with NE, and effects of Ang II were examined as in protocol 2. This concentration of 7-ER has been demonstrated to selectively inhibit cytochrome P-450 activity and to have no effect on the vasodilator action of Ach and sodium nitroprusside in the isolated perfused rat kidney (18)

6. Effect of $\mathrm{AT}_{2}$ receptor agonist in preconstricted Af-Arts in the presence or absence of 7-ER. To confirm that selective activation of $\mathrm{AT}_{2}$ receptor causes Af-Art dilation via a cytochrome P-450-dependent mechanism, we examined the effects of CGP $42112(N-\alpha-n i c o-$ tinolyl- $N-\epsilon-[N-\alpha$-benzyloxycarbonyl-Ang] Lys-His-Pro-Ile) (Neosystem, Strasbourg, France), an $\mathrm{AT}_{2}$ receptor agonist (19), on the luminal diameter of preconstricted Af-Arts in the presence or absence of 7-ER at $10^{-6} \mathrm{M}$. After the equilibration period, Af-Arts were preconstricted with $\mathrm{NE}(0.5 \mu \mathrm{M})$, and then increasing doses $\left(10^{-9}\right.$ $\left.10^{-6} \mathrm{M}\right)$ of CGP 42112 were added to both the bath and lumen. In another group, identical experiments were performed, except that 7-ER was present throughout the experiment.

7. Effect of EET in preconstricted Af-Art. Our results suggest that EETs may be involved in $\mathrm{AT}_{2}$ receptor-mediated vasodilation in the Af-Art (see Results). We therefore tested whether one of the authentic EETs, 11, 12-EET, causes vasodilation. Immediately before use, 11, 12-EET (Cayman Chemical Co., Inc., Ann Arbor, MI) was prepared in ethanol at $10^{-3} \mathrm{M}$, dilated with arteriolar perfusate, and administered into the lumen of preconstricted Af-Arts at final concentrations of $10^{-11}-10^{-8} \mathrm{M}$. Care was taken to avoid exposing the EET solutions to light. We have confirmed that ethanol had no effect on Af-Art reactivity at $10^{-5} \mathrm{M}$, the concentration for the highest dose of 11, 12-EET $\left(10^{-8} \mathrm{M}\right)$

8. Inhibiting $\mathrm{Ca}^{2+}$-activated $\mathrm{K}^{+}$channel. EETs have been shown to cause relaxation of vascular smooth muscle cells through activating a large-conductance $\mathrm{Ca}^{2+}$-activated $\mathrm{K}^{+}$channel (20-22). This channel is the most abundant one found in vascular smooth muscle cells of preglomerular arterioles $(23,24)$. We therefore examined whether blocking the large-conductance $\mathrm{Ca}^{2+}$-activated $\mathrm{K}^{+}$channel can abolish $\mathrm{AT}_{2}$ receptor-mediated vasodilation in the Af-Art. After the equilibration period, Af-Arts were treated with both $\mathrm{CV}\left(10^{-8} \mathrm{M}\right)$ and tetraethylammonium (TEA; $10^{-3} \mathrm{M}$, Sigma) for $30 \mathrm{~min}$. Af-Arts were then preconstricted with NE, and effects of Ang II were examined as in protocol 2. This concentration of TEA has been demonstrated to be selective for the large conductance $\mathrm{Ca}^{2+}$-activated $\mathrm{K}^{+}$ channel (25).

Data analysis. Values were expressed as mean \pm SEM, and all statistical analyses were carried out with absolute values. Student's paired $t$ test was used to examine whether the diameter at a given concentration differed from the pre-Ang II value (protocol 1) or preconstricted value (protocol 2-8) within each group. ANCOVA was used to examine whether dose-response curves differed between groups, and a two-sample $t$ test was used to examine whether the change in diameter at a given concentration differed between groups. 
$P<0.0125(0.05 / 4)$ was considered significant using Bonferroni's adjustment for multiple comparisons.

\section{Results}

Blockade of $A T_{1}$ or $A T_{2}$ receptor. Pretreatment with $\mathrm{CV}$ vehicle, $\mathrm{CV}$ at $10^{-9} \mathrm{M}, \mathrm{CV}$ at $10^{-8} \mathrm{M}$, or PD at $10^{-7} \mathrm{M}$ did not affect basal luminal diameter; the diameters before and after the treatment were 17.4 \pm 0.5 and 17.2 $\pm 0.5 \mu \mathrm{m}(n=7), 17.2 \pm 0.4$ and 17.0 $\pm 0.3 \mu \mathrm{m}(n=6), 17.1 \pm 0.5$ and 17.0 $\pm 0.4 \mu \mathrm{m}(n=6)$, or $17.1 \pm 0.4$ and $17.2 \pm 0.4 \mu \mathrm{m}(n=7)$, respectively. In the vehicle-treated Af-Arts, Ang II caused dose-dependent constriction; significant constriction was observed from $10^{-11} \mathrm{M}$ with the diameter decreasing by $2.0 \pm 0.3 \mu \mathrm{m}(12 \pm 2 \%, P<0.01)$. At $10^{-10}, 10^{-9}$, and $10^{-8} \mathrm{M}$, the diameter decreased by $4.6 \pm 0.6 \mu \mathrm{m}$ $(26 \pm 3 \%), 9.2 \pm 0.6(53 \pm 3 \%)$, and $12.6 \pm 0.8 \mu \mathrm{m}(73 \pm 5 \%)$, respectively (Fig. 1). Pretreatment with CV at $10^{-9} \mathrm{M}$ or $10^{-8} \mathrm{M}$ partly or completely inhibited this constriction, with the diameter decreasing by $6.4 \pm 1.0(37 \pm 6 \%)$ or $0.9 \pm 0.4 \mu \mathrm{m}(5 \pm 2 \%)$ at $10^{-8} \mathrm{M}$ Ang II, respectively. In Af-Arts pretreated with PD, Ang II at $10^{-11}, 10^{-10}, 10^{-9}$, and $10^{-8} \mathrm{M}$ decreased the diameter by $3.0 \pm 0.3(18 \pm 2 \%), 7.2 \pm 0.8(42 \pm 4 \%), 11.0 \pm 0.8(64 \pm 3 \%)$, and $14.2 \pm 0.8 \mu \mathrm{m}(82 \pm 4 \%)$, respectively. The decrease in diameter induced by Ang II differed significantly between vehicle and PD groups at $10^{-10} \mathrm{M}(P<0.01)$, while differences were statistically marginal at $10^{-11} \mathrm{M}(P=0.031)$ and $10^{-9} \mathrm{M}$ $(P=0.032)$.

Blockade of $A T_{1}$ receptor alone or both $A T_{1}$ and $A T_{2}$ receptors in preconstricted $A f$-Arts. Pretreatment with $C V$ vehicle, $\mathrm{CV}$, or $\mathrm{CV}$ plus PD did not affect basal luminal diameter; the diameter before and after the treatment was $17.1 \pm 0.5$ and $17.0 \pm 0.5 \mu \mathrm{m}(n=7), 17.1 \pm 0.4$ and 17.1 $\pm 0.4 \mu \mathrm{m}(n=7)$, or

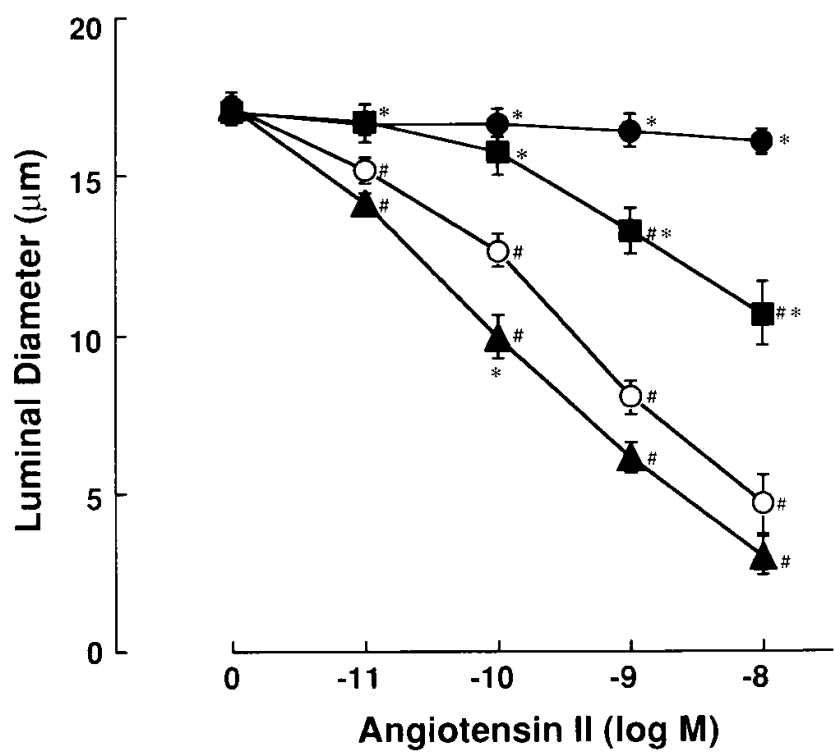

Figure 1. Effect of pretreatment with CV or PD on Ang II-induced vasoconstriction in Af-Arts. Ang II constricted vehicle-treated AfArts in a dose-dependent manner $(\mathrm{O}, n=7)$. Pretreatment with $\mathrm{CV}$ at $10^{-9} \mathrm{M}(\boldsymbol{\square}, n=6)$ or $10^{-8} \mathrm{M}(\boldsymbol{\bullet}, n=6)$ partly or completely inhibited this constriction, respectively. In contrast, pretreatment with PD at $10^{-7} \mathrm{M}(\boldsymbol{\Lambda}, n=7)$ significantly augmented the constriction. ${ }^{\#} P<$ 0.01 compared with pre-angiotensin II value, ${ }^{*} P<0.01$ compared with vehicle-treated group.

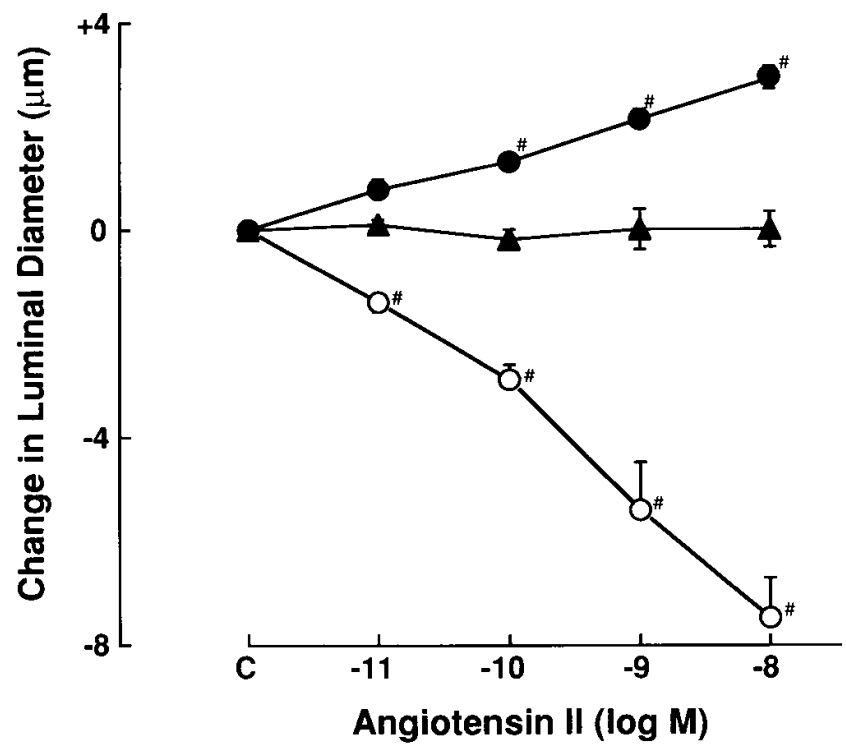

Figure 2. Effect of pretreatment with CV or CV plus PD on Ang II action in Af-Arts preconstricted with NE. The ordinate depicts changes in luminal diameter induced by Ang II over the NE-preconstricted level. In vehicle-treated and preconstricted Af-Arts, Ang II caused further dose-dependent constriction $(\bigcirc, n=7)$. In marked contrast, Ang II caused dose-dependent dilation in CV $\left(10^{-8} \mathrm{M}\right)$ treated and preconstricted Af-Arts $(\bullet, n=7)$. This dilation was completely abolished by simultaneous pretreatment with PD at $10^{-7} \mathrm{M}$ $(\boldsymbol{\Lambda}, n=6) .{ }^{\#} P<0.01$ compared with the preconstricted value.

17.0 \pm 0.4 and $17.1 \pm 0.4 \mu \mathrm{m}(n=6)$, respectively. NE decreased the diameter to $10.0 \pm 0.2,9.9 \pm 0.2$, or $9.8 \pm 0.2 \mu \mathrm{m}$, respectively. Fig. 2 depicts changes in luminal diameter induced by Ang II over the NE-preconstricted level in the three groups. In AfArts pretreated with vehicle, Ang II caused further constriction, with the diameter decreasing by $7.5 \pm 0.8 \mu \mathrm{m}$ (or $74 \pm 7 \%$ ) at $10^{-8} \mathrm{M}$. In marked contrast, in Af-Arts pretreated with CV, Ang II caused dose-dependent dilation. Significant dilation was observed from $10^{-10} \mathrm{M}$, which increased the diameter by $1.3 \pm 0.2 \mu \mathrm{m}$ or $13 \pm 2 \%(P<0.01)$, and at $10^{-9}$ and $10^{-8} \mathrm{M}$ the diameter increased by $2.1 \pm 0.2(21 \pm 2 \%)$ and $2.9 \pm 0.2 \mu \mathrm{m}$ $(29 \pm 2 \%)$, respectively (see the left panel of Fig. 6 for an example). On the other hand, simultaneous pretreatment with PD abolished the dilation observed in the presence of CV, suggesting an involvement of $\mathrm{AT}_{2}$ receptors.

Disruption of the endothelium. Treatment with antibodies against Factor VIII-related antigen and complements did not alter luminal diameter of Af-Arts, possible mechanisms for which have been discussed previously (13-15). The diameter before and after the treatment was 17.6 \pm 0.4 and 17.2 $\pm 0.5 \mu \mathrm{m}$, respectively $(n=10)$. In these Af-Arts, CV did not affect the luminal diameter $(17.4 \pm 0.4 \mu \mathrm{m})$. As previously reported, disruption of the endothelium with this procedure did not affect vasoconstrictor action of NE added to the bath (13-15); NE at $0.5 \mu \mathrm{M}$ decreased the diameter to $9.8 \pm 0.2 \mu \mathrm{m}$, a level similar to those observed in protocol 2. As shown in Fig. 3, Ang II had no effect in deendothelialized Af-Arts, demonstrating a crucial role of the endothelium in vasodilation mediated by $\mathrm{AT}_{2}$ receptors. At the end of each experiment, bath and lumen were washed out of Ang II for $20 \mathrm{~min}$. We then confirmed that Af- 


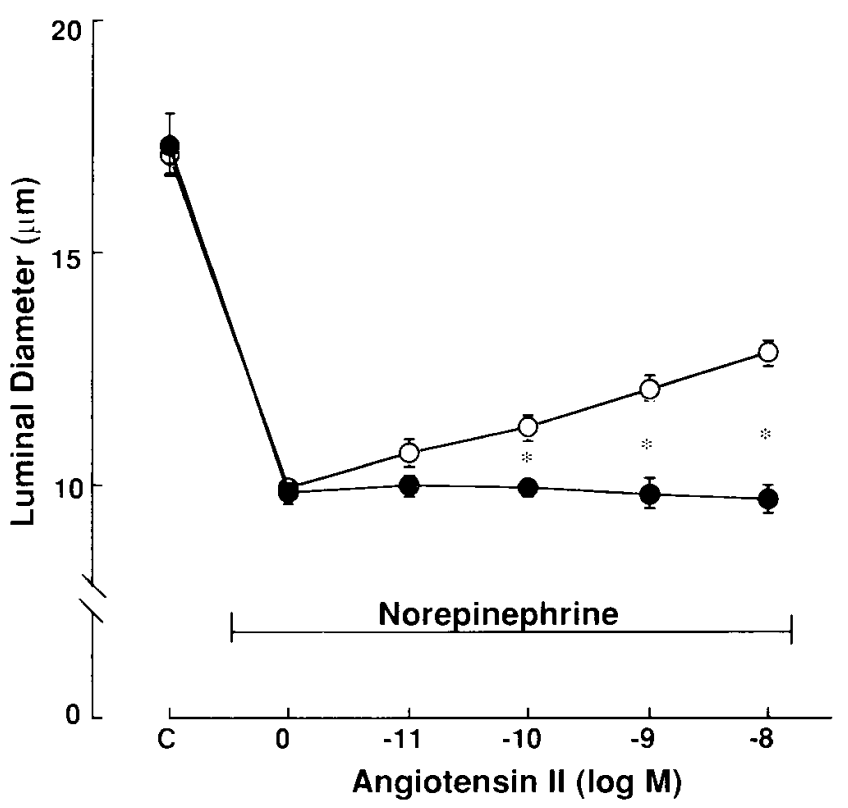

Figure 3. Effect of endothelial disruption on $\mathrm{AT}_{2}$ receptor-mediated dilation in Af-Arts. Disruption of the endothelium $(\bullet, n=6)$ abolished the Ang II-induced dilation in CV-pretreated and preconstricted Af-Arts observed in protocol $2(\bigcirc, n=7) . * P<0.01$ with vs. without endothelium.

Arts did not dilate in response to Ach at $10 \mu \mathrm{M}$ (before, $9.8 \pm 0.1 \mu \mathrm{m}$; after, $10.1 \pm 0.2 \mu \mathrm{m})$. In addition, in four experiments we confirmed that disruption of the endothelium does not affect responses to the endothelium-independent vasodilator nicardipine (Sigma Chemical Co.). After examining the effects of Ach, bath and lumen were washed out with control medium for $20 \mathrm{~min}$, the diameter returned to basal level $(18.0 \pm 0.3 \mu \mathrm{m})$, and then Af-Arts were again preconstricted with $\mathrm{NE}$ at $0.5 \mathrm{mM}$ to $10.4 \pm 0.2 \mu \mathrm{m}$. Nicardipine at $10^{-8}$ or $10^{-7}$ $\mathrm{M}$ increased the diameter by $36 \pm 5$ or $53 \pm 12 \%$, respectively. These effects of nicardipine were not different from those (42 \pm 5 and $57 \pm 4 \%$ for $10^{-8}$ and $10^{-7} \mathrm{M}$ nicardipine, respectively, $n=6$ ) observed in Af-Arts with intact endothelium.

Inhibiting synthesis of endothelium-derived vasodilators. Pretreatment with both CV and L-NAME significantly decreased the diameter by $21 \pm 3 \%$ from $16.9 \pm 0.2$ to $13.3 \pm 0.5$ $\mu \mathrm{m}(n=7)$, while pretreatment with both $\mathrm{CV}$ and either Indo or miconazole did not affect basal luminal diameter. The diameter before and after the treatment was $17.3 \pm 0.3$ and $17.2 \pm 0.4$ $\mu \mathrm{m}$ for $\mathrm{CV}$ with Indo $(n=7)$, or $17.0 \pm 0.4$ and $16.9 \pm 0.3 \mu \mathrm{m}$ for $\mathrm{CV}$ with miconazole $(n=7)$. Af-Arts were similarly preconstricted with NE $(0.2$ or $0.5 \mu \mathrm{M})$ to a diameter not different from those in protocol $2(9.7 \pm 0.3 \mu \mathrm{m}$ for $\mathrm{CV}$ with $\mathrm{L}-\mathrm{NAME}$, $10.0 \pm 0.3 \mu \mathrm{m}$ for $\mathrm{CV}$ with Indo, and $9.9 \pm 0.1 \mu \mathrm{m}$ for $\mathrm{CV}$ with miconazole). As shown in Fig. 4, in the presence of L-NAME or Indo, Ang II dilated Af-Arts in a dose-dependent manner; at $10^{-8} \mathrm{M}$ diameter increased by $2.8 \pm 0.5(29 \pm 6 \%)$ or $2.9 \pm 0.4$ $\mu \mathrm{m}(29 \pm 5 \%)$, respectively. In marked contrast, as shown in the left panel of Fig. 5, miconazole completely abolished the dilation induced by Ang II seen in the presence of CV (see right panel of Fig. 6 for an example). We confirmed that miconazole does not affect other mechanism-based vasodilations by using nicardipine $(n=5)$ and Ach $(n=6)$. In miconazole- pretreated and preconstricted Af-Arts, nicardipine at $10^{-8}$ or $10^{-7} \mathrm{M}$ increased the diameter by $35 \pm 5$ or $58 \pm 5 \%$, similar to the values obtained in nontreated Af-Arts (data given in the Results section of protocol 4). Ach at $10^{-6}$ or $10^{-5} \mathrm{M}$ increased the diameter of miconazole-pretreated and -preconstricted AfArts by $39 \pm 4$ or $70 \pm 8 \%$, similar to the values obtained in nontreated Af-Arts $\left(43 \pm 9\right.$ or $78 \pm 15 \%$ for $10^{-6}$ and $10^{-5} \mathrm{M}$ Ach, respectively, $n=5$ ).

Inhibiting cytochrome P-450 activity. Pretreatment with CV and 7-ER did not affect basal luminal diameter; the diameters before and after the treatment were 16.9 \pm 0.4 and $16.4 \pm 0.5$ $\mathrm{mm}(n=6)$, respectively. $\mathrm{NE}$ at $0.5 \mu \mathrm{M}$ decreased the diameter to $9.6 \pm 0.3 \mu \mathrm{m}$. As shown in the right panel of Fig. 5, Ang II did not cause significant dilation in such arterioles; at $10^{-8} \mathrm{M}$ the change in diameter was $1.0 \pm 0.5 \mu \mathrm{m}$, or $11 \pm 6 \%$ (NS). Thus, pretreatment with 7-ER also abolished $\mathrm{AT}_{2}$ receptormediated vasodilation in Af-Arts. We confirmed that 7-ER at $1 \mu \mathrm{M}$ does not affect nicardipine- or Ach-induced vasodilation; nicardipine at $10^{-8}$ or $10^{-7} \mathrm{M}$ and Ach at $10^{-6}$ or $10^{-5} \mathrm{M}$ both increased the diameter of 7-ER-pretreated and -preconstricted Af-Arts by $36 \pm 3$ or $64 \pm 2 \%(n=4)$ and $45 \pm 8$ or $65 \pm 8 \%(n=4)$, respectively, similar to the values obtained in nontreated Af-Arts.

Effect of $\mathrm{AT}_{2}$ receptor agonist in preconstricted $A f$-Arts in the presence or absence of 7-ER. NE decreased the diameter from $17.6 \pm 0.4$ to $9.6 \pm 0.2 \mu \mathrm{m}(n=8)$. CGP42112 added to both the bath and lumen caused dose-dependent dilation; significant dilation was observed from $10^{-7} \mathrm{M}$, which increased the diameter by $1.6 \pm 0.5 \mu \mathrm{m}$ (or $16 \pm 5 \%, P<0.01$ ), and at $10^{-6} \mathrm{M}$ the diameter increased by $2.1 \pm 0.5 \mu \mathrm{m}(22 \pm 5 \%)$. Pretreatment with 7-ER had no effect on basal luminal diameter, with mean values of $17.4 \pm 0.3$ and $17.3 \pm 0.3 \mu \mathrm{m}(n=5)$ before and after the treatment, respectively. Then, Af-Arts were preconstricted with $\mathrm{NE}$ to $9.6 \pm 0.2 \mu \mathrm{m}$. Under this condition, CGP42112 had no effect, with the luminal diameter being 9.6 \pm 0.4 and $9.7 \pm 0.3 \mu \mathrm{m}$ at $10^{-7}$ and $10^{-6} \mathrm{M}$, respectively.

Effect of EET in preconstricted Af-Arts. Basal luminal diameter was $17.2 \pm 0.7 \mu \mathrm{m}(n=5)$, which was reduced to $9.9 \pm 0.3 \mu \mathrm{m}$ with NE. Addition of 11, 12-EET caused dosedependent dilation with the diameter at $10^{-11}, 10^{-10}, 10^{-9}$, and $10^{-8} \mathrm{M}$ being $9.7 \pm 0.3$ (NS), 10.7 \pm 0.3 (NS), 11.5 $\pm 0.1(P<0.005)$, and 12.3 $\pm 0.4 \mu \mathrm{m}(P<0.01)$, respectively. Increases in diameter at $10^{-9}$ and $10^{-8} \mathrm{M}$ were $16 \pm 3$ and $24 \pm 7 \%$, respectively.

Inhibiting $\mathrm{Ca}^{2+}$-activated $\mathrm{K}^{+}$channels. Pretreatment with
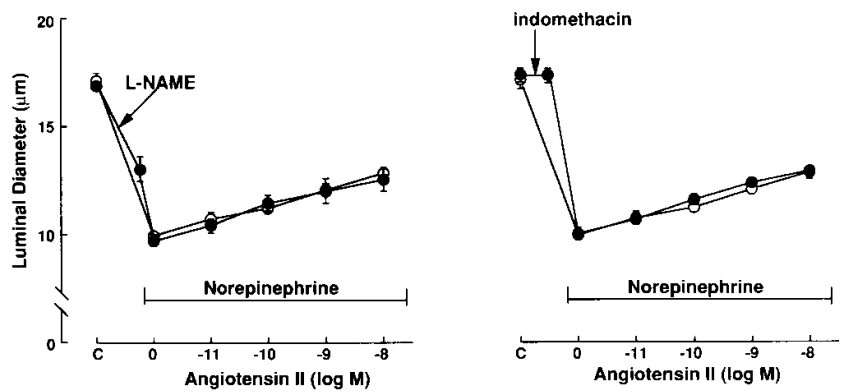

Figure 4. Effect of inhibition of NO synthase (left) or cyclooxygenase (right) on $\mathrm{AT}_{2}$ receptor-mediated dilation in Af-Arts. Treatment with either L-NAME at $10^{-4} \mathrm{M}(\bullet, n=7)$ or Indo at $5 \times 10^{-5} \mathrm{M}(\bullet, n=$ 7) had no effect on the Ang II-induced dilation in CV-pretreated and preconstricted Af-Arts observed in protocol $2(\bigcirc, n=7)$. 


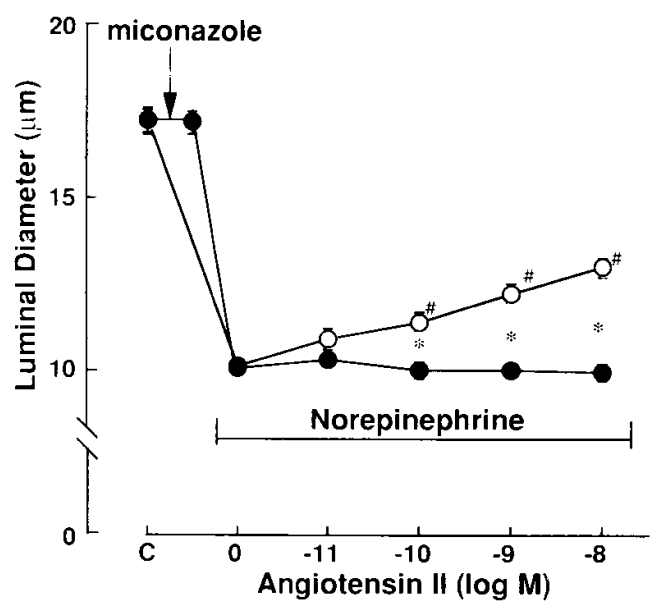

CV and TEA did not affect basal luminal diameter; the diameter before and after the treatment was $17.9 \pm 0.5$ and $17.1 \pm 0.5$ $\mu \mathrm{m}(n=6)$. In order to reduce the luminal diameter to a similar level to that attained in the other protocols $(9.6 \pm 0.3 \mu \mathrm{m})$, and since in our preliminary experiments we have found that blockade of the large-conductance $\mathrm{Ca}^{2+}$-activated $\mathrm{K}^{+}$channels with TEA potentiates vasoconstrictor action of NE, we used $\mathrm{NE}$ at $0.2 \mu \mathrm{M}$. As shown in Fig. 7, pretreatment with TEA completely abolished Ang II-induced vasodilation; at $10^{-8} \mathrm{M}$ change in diameter was $0.6 \pm 0.8 \mu \mathrm{m}$ or $7 \pm 10 \%$ (NS). This suggests that $\mathrm{Ca}^{2+}$-activated $\mathrm{K}^{+}$channels in vascular smooth muscle cells contribute to $\mathrm{AT}_{2}$ receptor-mediated vasodilation. We confirmed that TEA at $10^{-3} \mathrm{M}$ did not affect nicardipine- or Ach-induced vasodilation; nicardipine at $10^{-8}$ or $10^{-7} \mathrm{M}$ increased the diameter of TEA-pretreated and preconstricted AfArts by $33 \pm 7$ or $66 \pm 10 \%(n=5)$, respectively, while Ach at $10^{-6}$
CV

control

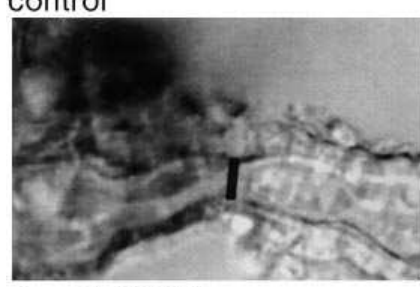

Ang $\| 10^{-8} \mathrm{M}$

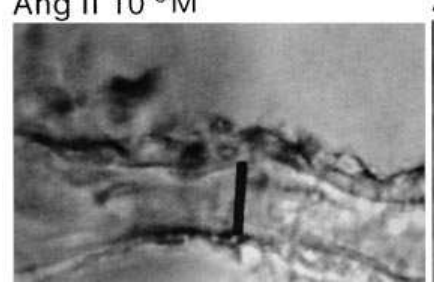

$\mathrm{CV}+$ miconazole control

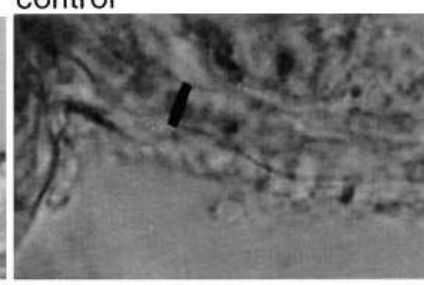

Ang $\| 10^{-8} \mathrm{M}$

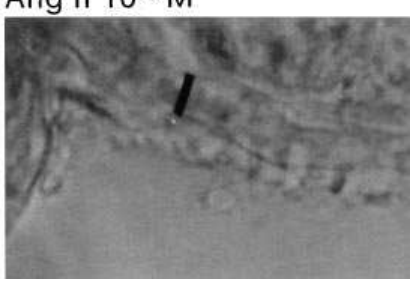

Figure 6. Ang II-induced dilation of Af-Art pretreated with CV and $\mathrm{NE}($ left $)$ and its blockade by miconazole (right). (Left) Af-Arts pretreated with $\mathrm{CV}\left(10^{-8} \mathrm{M}\right)$ and $\mathrm{NE}(0.5 \mu \mathrm{M})$. (Right) Af-Arts pretreated with $\mathrm{CV}, \mathrm{NE}$, and miconazole $\left(10^{-6} \mathrm{M}\right)$. Note that Ang II dilated preconstricted Af-Arts pretreated with $\mathrm{CV}$, and the dilation was abolished by miconazole. or $10^{-5} \mathrm{M}$ increased the diameter by $36 \pm 6$ or $61 \pm 9 \%(n=5)$, respectively, and these values are not different from those obtained in nontreated Af-Arts.

\section{Discussion}

In this study we examined the $\mathrm{AT}_{2}$ receptor-mediated action of Ang II on the Af-Art, a crucial vascular segment for controlling glomerular hemodynamics. We found that $(a)$ blockade of $\mathrm{AT}_{1}$ or $\mathrm{AT}_{2}$ receptor abolishes or augments the Ang IIinduced vasoconstriction in Af-Arts, respectively, and $(b)$ in preconstricted Af-Arts treated with an $\mathrm{AT}_{1}$ receptor antago-

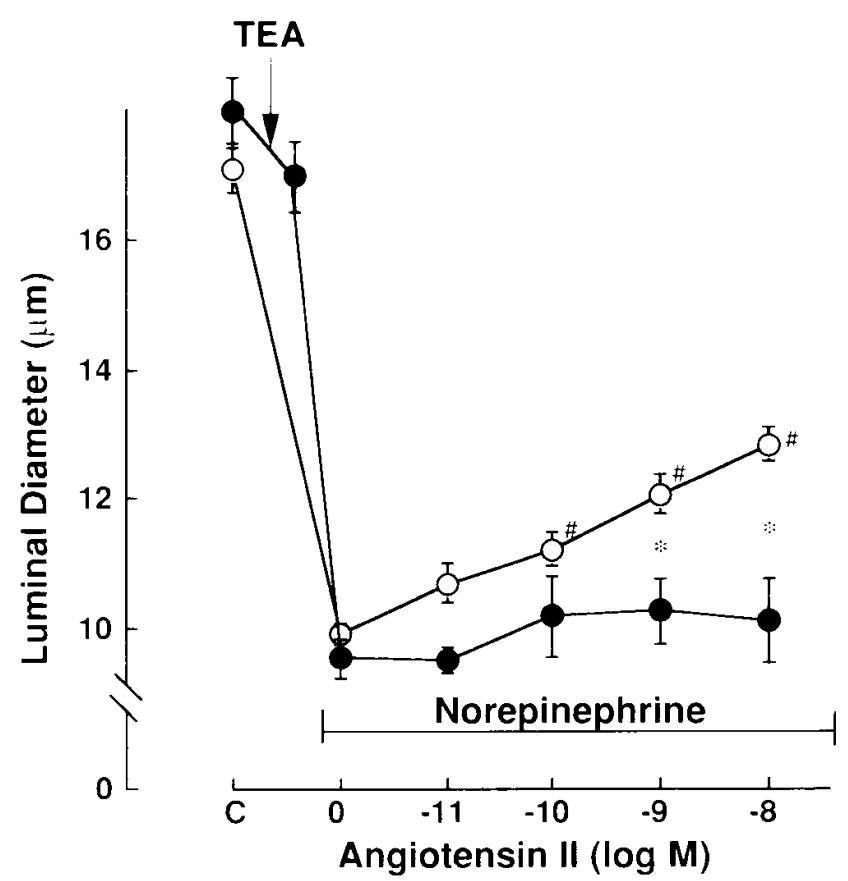

Figure 7. Effect of inhibition of $\mathrm{Ca}^{2+}$-activated $\mathrm{K}^{+}$channels on $\mathrm{AT}_{2}$ receptor-mediated dilation in Af-Arts. Pretreatment with TEA at $10^{-3} \mathrm{M}(\bullet, n=6)$ completely abolished the Ang II-induced dilation in CV-pretreated and preconstricted Af-Arts observed in protocol 2 $(\bigcirc, n=7) .{ }^{\#} P<0.01$ compared with preconstricted value, ${ }^{*} P<0.01$ compared with Af-Arts treated with $\mathrm{CV}$ and $\mathrm{NE}(\bigcirc)$. 
nist, Ang II now causes dose-dependent dilation that is abolished by $\mathrm{AT}_{2}$ receptor blockade. We also found that CGP 42112, an $\mathrm{AT}_{2}$ receptor agonist, causes dose-dependent dilation in preconstricted Af-Arts. Our findings are consistent with those of Ichiki et al. (4) and Hein et al. (26) that pressor response to exogenously infused Ang II is enhanced in mice lacking the gene encoding the $\mathrm{AT}_{2}$ receptor. Taken together, these studies suggest that activation of $\mathrm{AT}_{2}$ receptor is linked to a vasodilator mechanism that opposes vasoconstriction induced by $\mathrm{AT}_{1}$ receptor activation. In contrast, Hayashi et al. (27) reported that PD at $10 \mu \mathrm{M}$, a hundred times higher than what we used, attenuated Ang II-induced vasoconstriction in rat interlobular arteries, suggesting that $\mathrm{AT}_{2}$ receptors may mediate vasoconstriction as $\mathrm{AT}_{1}$ receptors do. The concentration used in their study, however, is rather high, and reportedly not selective for the $\mathrm{AT}_{2}$ receptor (12), raising the possibility that $\mathrm{AT}_{1}$ receptors were also blocked.

Observing $\mathrm{AT}_{2}$ receptor-mediated dilation of the Af-Art, we studied the mechanism involved. We particularly focused on the possible role of the endothelium and endotheliumderived vasoactive substances, since Ang II causes endothelium-dependent vasodilation in rabbit and rat cerebral arterioles $(28,29)$ which express only the $\mathrm{AT}_{2}$ receptor subtype (not $\mathrm{AT}_{1}$ receptor; 30 ). We found that disruption of the endothelium abolished the dilation, demonstrating a crucial role of the endothelium. Inhibition of either NO or PG synthesis, however, was without effect, while inhibition of EETs synthesis or cytochrome P-450 activities with miconazole or 7-ER, respectively, abolished the dilation completely. In addition, we confirmed that one of the authentic EETs, 11-12 EET, dilates preconstricted Af-Arts. Taken together, these results suggest that in the Af-Art, selective activation of $\mathrm{AT}_{2}$ receptors may cause endothelium-dependent vasodilation via a cytochrome P-450 pathway, possibly EETs. In support of this notion is our finding that pretreatment with TEA, which inhibits the vascular action of EETs by blocking $\mathrm{Ca}^{2+}$-activated $\mathrm{K}^{+}$channel, also abolished the $\mathrm{AT}_{2}$ receptor-mediated vasodilation. This protocol was not designed to examine the mechanism by which EETs relax Af-Arts, and there are some limitations (i.e., specificity of TEA). Nevertheless, the finding is consistent with other results, suggesting a possible role of EETs in $\mathrm{AT}_{2}$ receptor-mediated dilation in the Af-Art.

We found that NO synthesis inhibition with L-NAME had no effect on $\mathrm{AT}_{2}$ receptor-mediated vasodilation in Af-Arts, suggesting that activation of $\mathrm{AT}_{2}$ receptor does not stimulate NO release in Af-Arts. This notion is supported by the findings of Boulanger et al. (31), that Ang II stimulates release of $\mathrm{NO}$ from the vascular endothelium through $\mathrm{AT}_{1}$ but not $\mathrm{AT}_{2}$ receptors. In contrast, using a unique renal interstitial fluid microdialysis system, Siragy and Carey $(32,33)$ recently reported that administration of exogenous Ang II or activation of the endogenous renin-angiotensin system with a low-sodium diet increased renal interstitial cyclic GMP level by stimulating NO production. Since an $\mathrm{AT}_{2}$ receptor antagonist attenuated the increase in cyclic GMP and NO production, they suggested that $\mathrm{AT}_{2}$ receptors are coupled to the NO pathway within the kidney. The reason for the apparent discrepancy between our results and theirs may be related to the origin of cyclic GMP and NO measured in their study. Within the kidney NO is produced not only by the vascular endothelium, but also by several tubular segments including the macula densa (34-36) as well as infiltrated macrophages. Thus, it is possible that activa- tion of $\mathrm{AT}_{2}$ receptor may stimulate the production of $\mathrm{NO}$ in several cell types other than vascular endothelial cells. In addition, chronic activation of the renin-angiotensin system with sodium depletion or exogenous Ang II may have altered renal expression of NO synthase. Indeed, Singh et al. (37) have recently demonstrated that a low-sodium diet elevates expression of the neuronal form of the constitutive NO synthase in the macula densa cells, but it does not affect endothelial NO synthase activity in the renal cortex. Tojo et al. (36) also have reported that in rats, a low-sodium diet increases immunostaining for constitutive NO synthase in the macula densa cells as well as for inducible NO synthase in the vascular smooth muscle cells of Af-Arts. Interestingly, infusion of losartan, an $\mathrm{AT}_{1}$ receptor antagonist, also enhanced the intensity of immunoreactive staining for both isoforms, suggesting that the enhancement is due to activation of Ang II receptors other than the $\mathrm{AT}_{1}$ subtype, possibly the $\mathrm{AT}_{2}$. Although activation of $\mathrm{AT}_{2}$ receptor may induce $\mathrm{NO}$ synthase in the vascular smooth muscle cells of Af-Arts, it is unlikely that such mechanisms were involved in the dilation we observed since induction of NO synthase in the vascular smooth muscle cells requires hours (38), a period much longer than that needed to complete our protocols.

In our previous studies examining the action of Ang II on rabbit Af-Arts, we added Ang II only to the bath, and found that Ang II did not cause significant constriction until the concentration reached $10^{-9} \mathrm{M}$ (39). In contrast, in this study we gave Ang II to both the bath and lumen since $\mathrm{AT}_{2}$ receptors have been demonstrated to be expressed by the endothelium (40). We found that Ang II added to both the bath and lumen causes significant constriction at concentrations as low as $10^{-11}$ M. While the reason for such higher sensitivities to Ang II is not clear, this finding is consistent with our recent study (41) showing that Ang II added to the lumen causes much stronger constriction than that observed with Ang II added to the bath. Thus, it seems that Af-Arts have a higher sensitivity to luminal than interstitial Ang II. Such a difference in Ang II sensitivity may explain a paradox that despite high renal interstitial Ang II levels (nanomolar range; 42), an infusion of Ang II that raises arterial Ang II levels only by $50-100$ pM, still elicits renal vasoconstriction.

Recently, a number of studies have focused attention on a possible physiological role of cytochrome P-450 metabolites of AA in vascular tone regulation. In the kidney, the cytochrome P-450 enzymes metabolize AA to a series of EETs (5,6-, 8,9-, 11,12- or 14,15-EET) and 19- or 20-hydroxyeicosatetraenoic acid (19- or 20-HETE; 43). Among them, the physiological importance of 20-HETE in control of renal hemodynamics has been studied extensively. For example, studies suggest that 20 HETE may participate in the tubuloglomerular feedback (44) as well as the myogenic response of the Af-Art (45), playing an important role in renal blood flow autoregulation (17). We also have demonstrated that 20-HETE causes endotheliumand cyclooxygenase-dependent vasoconstriction in rabbit Af-Arts (46). In addition, 20-HETE has been reported to modulate the $\mathrm{Na}^{+}-\mathrm{K}^{+}-2 \mathrm{Cl}^{-}$cotransporter of the medullary thick ascending limb of Henle's loop (47), and to contribute significantly to blood pressure elevation in spontaneously hypertensive rats (48) and in rabbits with aortic coarctation (49). On the other hand, the importance of EETs in glomerular hemodynamic regulation remains to be elucidated. Several recent studies have shown that EETs represent the endothelium- 
derived hyperpolarizing factor (50-52), which may be important in the control of glomerular hemodynamics. Zou et al. (17, 53) have demonstrated that preglomerular microvessels produce EETs, and that EETs cause vasodilation of preglomerular microvessels by activating $\mathrm{Ca}^{2+}$-activated $\mathrm{K}^{+}$channels. Consistent with these studies, our results also suggest that endogenous production of EETs may play a role in the control of Af-Art tone. In addition, this study may suggest that one of the physiological stimuli of EETs production in the Af-Art might be Ang II (through $\mathrm{AT}_{2}$ receptor).

We have previously demonstrated that Ang II stimulates the production of EETs in rat proximal tubular cells (54). In addition, Madhun et al. (55) have reported that in rabbit proximal tubular epithelial cells Ang II stimulates production of EETs, which in turn mediate Ang II-induced calcium mobilization. Although these findings suggest that EETs have a significant role in the signaling pathway of Ang II in the proximal tubule cells, our study may be considered the first suggesting that EETs possibly participate in controlling Af-Art tone by Ang II. Studies have shown that the vascular endothelium is capable of metabolizing AA to all four EETs (5,6-, 8,9-, 11,12-, and 14,15-EET; 22). It has been reported that the major EETs synthesized in rabbit kidney and rat preglomerular microvessels are 11,12- and 14,15-EET $(17,56)$, and that 11,12- but not 14,15 -EET, causes significant vasodilation in both isolated perfused rabbit kidney (57) and rat preglomerular microvessels of the juxtamedullary nephron preparation (53). Consistent with these studies, we found that 11,12-EET dilated preconstricted Af-Arts. Thus, it may be speculated that the mechanism for the Af-Art dilation induced by activation of $\mathrm{AT}_{2}$ receptor in this study may involve 11,12-EET.

It is well known that Ang II plays an important role in the control of renal function (8). Although most of its renal actions are mediated by $\mathrm{AT}_{1}$ receptors, some studies have demonstrated that Ang II regulates renal function partly through $\mathrm{AT}_{2}$ receptors $(32,33,58,59)$. We found that in the presence of $\mathrm{AT}_{1}$ receptor antagonist, Ang II at $\mathrm{nM}$ concentrations increased the diameter of preconstricted Af-Arts by $~ 20-30 \%$, which represents as much as a $50 \%$ decrease in vascular resistance (the vascular resistance is proportional to the reciprocal of fourth power of radius). The dilation was abolished by the specific $\mathrm{AT}_{2}$ receptor antagonist as well as by miconazole and 7-ER. While results were obtained by pharmacological interventions (there are some limitations, i.e., specificity of the inhibitors), our results may suggest the possibility that the $\mathrm{AT}_{2}$ receptor is coupled to EETs production, which in turn opposes Af-Art constriction mediated by the $\mathrm{AT}_{1}$ receptor. Such modulation by the $\mathrm{AT}_{2}$ receptor and its alteration may play an important role in various physiological and pathological conditions.

\section{Acknowledgments}

We thank Drs. J.A. Keiser and J.C. Hodges (Parke-Davis Laboratories, Ann Arbor, MI) who kindly provided us with PD 123319. CV 11974 was graciously provided by Takeda Chemical Industries Ltd. (Osaka, Japan). The authors gratefully thank Miss Hiromi Takahashi and Miss Akiko Kohinata for their secretarial assistance and Miss Akiko Umetsu for her technical assistance.

This work was supported by grants from the Ministry of Science, Education and Culture, Japan (no. 07457237, no. 07457238 and no. 08457283).

\section{References}

1. Whitebread, S., M. Mele, B. Kamber, and M. DeGasparo. 1989. Preliminary biochemical characterization of two angiotensin II receptor subtypes. Biochem. Biophys. Res. Commun. 163:284-291.

2. Chiu, A.T., W.F. Herblin, R.J. Ardecky, D.E. McCall, D.J. Carini, J.V. Duncia, L.J. Pease, R.R. Wexler, P.C. Wong, A.L. Johnson, and P.B.M.W.M. Timmermans. 1989. Identification of angiotensin II receptor subtypes. Biochem. Biophys. Res. Commun. 165:196-203.

3. Timmermans, P.B.M.W.M., P.C. Wong, A.T. Chiu, W.F. Herblin, P. Benfield, D.J. Carini, R.J. Lee, R.R. Wexler, J.A.M. Saye, and R.D. Smith. 1993. Angiotensin II receptors and angiotensin II receptor antagonists. Pharmacol. Rev. 45:205-251.

4. Ichiki, T., P.A. Labosky, C. Shiota, S. Okuyama, Y. Imagawa, A. Fogo, F. Niimura, I. Ichikawa, B.L.M. Hogan, and T. Inagami. 1995. Effects on blood pressure and exploratory behavior of mice lacking angiotensin II type-2 receptor. Nature. 377:748-750.

5. Munzenmaier, D.H., and A.S. Greene. 1996. Opposing actions of angiotensin II on microvascular growth and arterial blood pressure. Hypertension (NY). 27:760-765

6. Ito, S., O.A. Carretero, and R.D. Murray. 1985. Possible role of adenosine in the macula densa mechanism of renin release in rabbits. J. Clin. Invest. 76:1412-1417.

7. Ito, S., and O.A. Carretero. 1990. An in vitro approach to the study of madula densa-mediated glomerular hemodynamids. Kidney Int. 38:1206-1210.

8. Ito, S., C.S. Johnson, and O.A. Carretero. 1991. Modulation of angiotensin II-induced vasoconstriction by endothelium-derived relaxing factor in the isolated microperfused rabbit afferent arteriole. J. Clin. Invest. 87:16561663.

9. Arima, S., S. Ito, K. Omata, K. Takeuchi, and K. Abe. 1995. High glucose augments angiotensin II action by inhibiting NO synthesis in in vitro microperfused rabbit afferent arterioles. Kidney Int. 48:683-689.

10. Shibouta, Y., Y. Inada, M. Ojima, T. Wada, M. Noda, T. Sanada, K. Kubo, Y. Kohara, T. Naka, and K. Nishikawa. 1993. Pharmacological profile of a highly potent and long-acting angiotensin II receptor antagonist, 2-ethoxy1-[[2'-(1H-tetrazol-5-yl)biphenyl-4-yl]methyl]-1H-benzimidazole-7-carboxylic acid (CV11974), and its prodrug, ( \pm )-1 (cyclohexyloxycarbonyloxy)-ethyl2-ethoxy1-[[2'-(1H-tetrazol-5-yl)biphenyl-4-yl]methyl]-1H-benzimidazole-7-carboxylate (TCV 116). J. Pharmacol. Exp. Ther. 266:114-120.

11. Macari, D., S. Bottani, S. Whitebread, M. De Gasparo, and N. Levens. 1993. Renal actions of the selective angiotensin $\mathrm{AT}_{2}$ receptor ligands CGP 42112 B and PD 123319 in the sodium-depleted rat. Eur. J. Pharmacol. 249:8593.

12. Berchler, V., P.W. Jones, N.R. Levens, M. de Gasparo, and S.P. Bottari. 1993. Agonistic and antagonistic properties of angiotensin analogs at the $\mathrm{AT}_{2}$ receptor in PC12W cells. Regul. Pept. 44:207-213.

13. Juncos, L.A., S. Ito, O.A. Carretero, and J.L. Garvin. 1994. Removal of endothelium-dependent relaxation by antibody and complement in afferent arterioles. Hypertension (NY). 23(1):I54-59.

14. Juncos, L.A., J. Garvin, O.A. Carretero, and S. Ito. 1995. Flow modulates myogenic responses in isolated microperfused rabbit afferent arterioles via endothelium-derived nitirc oxide. J. Clin. Invest. 95:2741-2748.

15. Juncos, L.A., Y.L. Ren, S. Arima, J. Garvin, O.A. Carretero, and S. Ito. 1996. Angiotensin II action in isolated microperfused rabbit afferent arterioles is modulated by flow. Kidney Int. 49:374-381.

16. Itoh, S., and O.A. Carretero. 1985. Role of macula densa in renin release. Hypertension (NY). 7(1):I49-I54.

17. Zou, A.P., J.D. Imig, M. Kaldunski, P.R. Ortiz De Montellano, Z. Sui, and R.J. Roman. 1994. Inhibition of renal vascular 20-HETE production impairs autoregulation of renal blood flow. Am. J. Physiol. 266:F275-F282.

18. Oyekan, A.O., J.C. McGiff, and J. Quilley. 1991. Cytochrome P-450dependent vasodilator responses to arachidonic acid in the isolated perfused kidney of the rat. Circ. Res. 68:958-965.

19. Tsuzuki, S., T. Matoba, S. Eguchi, and T. Inagami. 1996. Angiotensin II type 2 receptor inhibits cell proliferation and activates tyrosine phosphatase. Hypertension (NY). 28:916-918.

20. Gebremedhin, D., Y.H. Ma, J.R. Falck, R.J. Roman, M. VanRollins, and D.R. Harder. 1992. Mechanism of action of cerebral epoxyeicosatrienoic acids on cerebral arterial smooth muscle. Am. J .Physiol. 263:H519-H525.

21. Hu, S., and H.S. Kim. 1993. Activation of $\mathrm{K}^{+}$channels in vascular smooth muscles by cytochrome $\mathrm{P} 450$ metabolites of arachidonic acid. Eur. J. Pharmacol. 230:215-221.

22. Harder, D.R., W.B. Campbell, and R.J. Roman. 1995. Role of cytochrome P-450 enzymes and metabolites of arachidonic acid in the control of vascular tone. J. Vasc. Res. 32:79-92.

23. Gebremedhin, D., E.R. Kaldunski, E.R. Jacobs, D.R. Harder, and R.J. Roman. 1996. Coexistence of two types of $\mathrm{Ca}^{2+}$-activated $\mathrm{K}^{+}$channels in rat renal arterioles. Am. J. Physiol. 270:F68-F81.

24. Zou, A.P., J.D. Imig, M. Kaldunski, P.R. Ortiz de Montellano, Z. Sui, and R.J. Roman. 1996. 20-HETE is an endogenous inhibitor of the large-conductance $\mathrm{Ca}^{2+}$-activated $\mathrm{K}^{+}$channel in renal arterioles. Am. J. Physiol. 270: R228-R237. 
25. Langton, P.D., M.T. Nelson, Y. Huang, and N.B. Standen. 1991. Block of calcium-activated potassium channels in mammalian arteriolar myocytes by tetraethylammonium ions. Am. J. Physiol. 260:H927-H934.

26. Hein, L., G.S. Barsh, R.E. Pratt, V.J. Dzau, and B.K. Kobilka. 1995. Behavioral and cardiovascular effects of disrupting the angiotensin II type-2 receptor gene in mice. Nature. 377:744-747.

27. Hayashi, K., H. Suzuki, and T. Saruta. 1993. Segmental differences in angiotensin receptor subtypes in interlobular artery of hydronephrotic rat kidneys. Am. J. Physiol. 265:F881-F885.

28. Haberl, R.L., F. Anneser, A. Villringer, and K.M. Einhaupl. 1990. Angiotensin II induces endothelium-dependent vasodilation of rat cerebral arterioles. Am. J. Physiol. 258:H1840-H1846.

29. Haberl, R.L., P.J. Decker, and K.M. Einhaupl. 1991. Angiotensin degradation products mediate endothelium-dependent dilation of rabbit brain arterioles. Circ. Res. 68:1621-1627.

30. Tsutsumi, K., and J.M. Saavedra. 1991. Characterization of $\mathrm{AT}_{2}$ angiotensin II receptors in rat anterior cerebral arteries. Am. J. Physiol. 261:H667H670.

31. Boulanger, C.M., L. Caputo, and B.I. Levy. 1995. Endothelial AT -medi- $^{-}$ ated release of nitric oxide decreases angiotensin II contraction in rat carotid artery. Hypertension (NY). 26:752-757.

32. Siragy, H.M., and R.M. Carey. 1996. The subtype-2 $\left(\mathrm{AT}_{2}\right)$ angiotensin receptor regulates renal cyclic guanosine $3^{\prime}, 5^{\prime}$-monophosphate and $\mathrm{AT}_{1}$ receptor-mediated prostaglandin $\mathrm{E}_{2}$ production in conscious rats. J. Clin. Invest. 97: 1978-1982.

33. Siragy, H.M., and R.M. Carey. 1996. The angiotensin $\mathrm{AT}_{2}$ receptor stimulates renal production of nitric oxide (NO) during sodium $(\mathrm{Na})$ depletion. $H y$ pertension (NY). 28:516. (Abstr.)

34. Mundel, P., S. Bachmann, M. Bader, A. Fischer, W. Kummer, B. Mayer, and W. Kriz. 1992. Expression of nitric oxide synthase in kidney macula densa cells. Kidney Int. 42:1017-1019.

35. Wilcox, C.S., W.J. Welch, F. Murad, S.S. Gross, G. Taylor, R. Levi, and H.H.W. Schmidt. 1992. Nitric oxide synthase in macula densa regulates glomerular capillary pressure. Proc. Natl. Acad. Sci. USA. 89:11993-11997.

36. Tojo, A., K.M. Madsen, and C.S. Wilcox. 1995. Expression of immunoreactive nitric oxide synthase isoforms in rat kidney. Effects of dietary salt and losartan. Jpn. Heart J. 36:389-398.

37. Singh, I., M. Grams, W.H. Wang, T. Yang, P. Killen, A. Smart, J. Schnermann, and J.P. Briggs. 1996. Coordinate regulation of renal expression of nitric oxide synthase, renin, and angiotensinogen mRNA by dietary salt. Am. J. Physiol. 270:F1027-F1037.

38. Moncada, S., R.M. Palmer, and E.A. Higgs. 1991. Nitric oxide: physiology, pathophysiology, and pharmacology. Pharmacol. Rev. 43:109-142.

39. Ito, S., S. Arima, Y.L. Ren, L.A. Juncos, and O.A. Carretero. 1993. Endothelium-derived relaxing factor/nitric oxide modulates angiotensin II action in the isolated microperfused rabbit afferent but not efferent arteriole. J. Clin. Invest. 91:2012-2019.

40. Stoll, M., U.M. Steckelings, P. Martin, S.P. Bottari, R. Metzger, and T. Unger. 1995. The angiotensin $\mathrm{AT}_{2}$-receptor mediates inhibition of cell proliferation in coronary endothelial cells. J. Clin. Invest . 95:651-657.

41. Ito, S., J. Amin, Y.L. Ren, S. Arima, K. Abe, and O.A. Carretero. Heterogeneity of angiotensin action in renal circulation. Kidney Int. In press.

42. Siragy, H.M., N.L. Howell, N.V. Ragsdale, and R.M. Carey. 1995. Renal interstitial fluid angiotensin modulation by anesthesia, epinephrine, sodium de- pletion, and renin inhibitor. Hypertension (NY). 25:1021-1024.

43. McGiff, J.C. 1991. Cytochrome P-450 metabolism of arachidonic acid. Annu. Rev. Pharmacol. Toxicol. 31:339-369.

44. Zou, A.P., J.D. Imig, P.R. Ortiz De Montellano, Z. Sui, J.R. Falck, and R.J. Roman. 1994. Effect of P-450- $\omega$-hydroxylase metabolites of arachidonic acid on tubuloglomerular feedback. Am. J. Physiol. 266:F934-F941.

45. Imig, J.D., A.P. Zou, P.R. Ortiz De Montellano, Z. Sui, J.R. Falck, and R.J. Roman. 1994. Cytochrome P-450 inhibitors alter afferent arteriolar responses to elevations in perfusion pressure. Am. J. Physiol. 266:H1879-H1885.

46. Arima, S., K. Omata, S. Ito, K. Tsunoda, and K. Abe. 1996. 20-HETE requires increased vascular tone to constrict rabbit afferent arterioles. Hypertension (NY). 27:781-785.

47. Escalante, B., D. Erlij, J.R. Falck, and J.C. McGiff. 1991. Effect of cytochrome P-450 arachidonate metabolites on ion transport in rabbit kidney loop of Henle. Science. 251:799-802.

48. Sacerdoti, D., B. Escalante, N.G. Abraham, J.C. McGiff, R.D. Levere and M.L. Schwartzman. 1989. Treatment with tin prevents the development of hypertension in spontaneously hypertensive rats. Science. 243:388-390.

49. Carroll, M.A., M.L. Schwartzman, M. Baba, M.J.S. Miller, and J.C. McGiff. 1988. Renal cytochrome P-450-related arachidonate metabolism in rabbit aortic coarctation. Am. J. Physiol. 255:F151-F157.

50. Hecker, M., A. Bara,. J. Bauersachs, and R. Busse. 1994. Characterization of endothelium-derived hyperpolarizing factor as a cytochrome P450dependent arachidonic acid metabolite in mammals. J. Physiol (Lond.). 4812: 407-414.

51. Fulton, D., K. Manboubi, J.C. McGiff, and J. Quilley. 1995. Cytochrome P450-dependent effects of bradykinin in the rat heart. Br. J. Pharmacol. 114:99102.

52. Campbell, W.B., D. Gebremedhin, P.F. Pratt, and D.R. Harder. 1996 Identification of epoxyeicosatrienoic acids as endothelium-derived hyperpolarizing factors. Circ. Res. 78:415-423.

53. Zou, A.P., J.T. Fleming, J.R. Falck, E.R. Jacob, D. Gebremedhin, D.R. Harder, and R.J. Roman. 1996. Stereospecific effects of epoxyeicosatrienoic ac ids on renal vascular tone and $\mathrm{K}^{+}$-channel activity. Am. J. Physiol. 270:F822F832.

54. Omata, K., N.G. Abraham, and M.L. Schwartzman. 1992. Renal cytochrome P-450-arachidonic acid metabolism: localization and hormonal regulation in SHR. Am. J. Physiol. 262:F591-F599.

55. Madhum, Z.T., D.A. Goldthwait, D. McKay, U. Hopfer, and J.G. Douglas. 1991. An epoxygenase metabolite of arachidonic acid mediates angiotensin II-induced rises in cytosolic calcium in rabbit proximal tubule epithelial cells. $J$. Clin. Invest. 88:456-461.

56. Schwartzman, M.L., N.G. Abraham, M.A. Carroll, R.D. Levere, and J.C. McGiff. 1986. Regulation of arachidonic acid metabolism by cytochrome P-450 in rabbit kidney. Biochem. J. 238:283-290.

57. Carroll, M.A., M.P. Garcia, J.R. Falck, and J.C. McGiff. 1992. Cyclooxygenase dependency of the renovascular actions of cytochrome P-450 derived arachidonic acid metabolites. J. Pharmacol. Exp. Ther. 260:104-109.

58. Lo, M., K. Liu, P. Lamtelme, and J. Sassard. 1995. Subtype 2 of angiotensin II receptors controls pressure natriuresis in rats. J. Clin. Invest. 95:13941397.

59. Jacobs, L.S., and J.G. Douglas. 1996. Angiotensin II type 2 receptor subtype mediates phospholipase A2-dependent signaling in rabbit proximal tubular epithelial cells. Hypertension (NY). 28:663-668. 